\title{
Exploration and Practice of Cultivating Innovative Talents in Colleges and Universities from the Perspective of Ideological and Political Education*
}

\author{
Mingchao Li \\ Zhuhai College of Jilin University \\ Zhuhai, China
}

\begin{abstract}
With the rapid development of economy and science and technology, to cultivate innovative talents has become major historical mission for higher education given by the times. In the cultivation of innovative talents, the role of ideological and political education is fully played. It is of great significance to deepen and expand the field of ideological and political education, and to improve the pertinence and effectiveness of ideological and political education.
\end{abstract}

Keywords-ideological and political education; colleges and universities; cultivation of innovative talents; exploration

\section{INTRODUCTION}

For a long time, ideological and political education has played an important role in ensuring the direction of personnel training in higher education and consolidating the guiding position of Marxism in the field of ideology. However, ideological and political education in colleges and universities is social practice to educate the students. It should always be committed to creating the conditions for free and all-round development of mankind. Therefore, the colleges and universities should cultivate the subjectivity and creative thinking of human beings, shape healthy personality and cultivate humane spirit. We should analyze the role of ideological and political education in the training of creative talents in colleges and universities. It is conducive to reflecting the essence of ideological and political education in colleges and universities. Also, it could meet the objective needs of contemporary college students. And then, they would achieve the development.

With the rapid development of the knowledge-based economy, the progress in science and technology, and increasingly fierce international competition, the construction of national innovation system has been widely carried out all over the world. For China, there is no exception in keeping with the tide of the times. In the process of building innovative nation, it is necessary to talk about the innovation in the 21st century. The report of the 19th CPC National Congress once again made clear and general

*Project Source: This article is staged achievements of "exploration and practice of cultivating innovative talents in colleges and universities from the perspective of ideological and political education". And it is key platform and major research project for young innovative talents in colleges and universities of Guangdong province in 2017. requirements for the construction of an "innovative nation". In the report, it pointed out the concept of "accelerating the construction of an innovative country". Innovation is the first motivation to lead the development. Also, it is strategic support for building a modern economic system. The main body of innovation is human. To achieve the innovation, we must have the innovative personnel. And the training of innovative talents relies on education. The colleges and universities are the main front for training innovative personnel. From the proposal of building an "innovative nation" to the report of 19th CPC National Congress, "from 2002 to 2015, China's economic strength and technological strength will soar to the forefront among innovative countries." "And it should cultivate a large number of international strategic science and technology personnel, science and technology leaders, young scientists and technicians and high-level innovation team." It can be seen that cultivation of high-level innovative talents should meet the requirements of the times. And it is related to the overall layout of socialist modernization. In "national long-term education reform and development (2010-2020)", it pointed out that innovative training model should be adapted to the needs of national and social development. And innovative training model should follow the law of education and the law of talent growth. Also, it should deepen the reform of education and teaching, innovate the teaching methods of education, and explore various modes of cultivation. The various types of top-notch innovative talents continue to emerge. [1] Ideological and political education in colleges and universities is continuous project. And the cultivation of innovative talents is the enrichment and development of content for ideological and political education in colleges and universities. It is also the innovation and improvement of educational philosophy and educational goals. It is shown in this paper. Therefore, it is of intrinsic theoretical significance to continuously strengthen and improve the ideological and political education in colleges and universities for the cultivation of innovative talents.

\section{THE INHERENT REGULATION OF INNOVATIVE PERSONNEL}

It should analyze the role of ideological and political education in the cultivation of creative talents in colleges and 
universities. It is necessary to analyze the connotation of "creative talents" first, which is the logical premise of carrying out research.

The concept of innovative talent could be divided into broad sense and narrow sense. In the broad sense, it is the contrast of the unscrupulous and conservative people. Therefore, in general, the performance and extent of the innovative talents are different. Narrowly, the innovative talents refer to those who have the noble moral character and the devotion spirit. With active innovation desire and strict innovative thinking, the innovative talents would actively explore their own potential for innovation. And they would be committed to the pursuit and exploration of truth. In the scientific research process, the innovative talents would actively participate in innovation and practice. And then, the innovative talents would make innovations, recognize and transform the world for mankind, and make beneficial contributions to the development of social economy and science and technology [2]. Innovative talent discussed in this article mainly refers to the innovation talents in narrow sense. Obviously, in the process of training creative talents, the factors such as innovation spirit, innovative thinking and innovative ability are indispensable. However, various elements simply composed can't constitute innovative talents. And innovative talents should be based on the free development of independent individuals. Also, it is based on the personal subjectivity. The content of enhancing the creative quality of man and the innovative abilities is basic. It takes the innovative actions as the symbol. And it should take the practice as the approach. Innovative talent is not the contrast concept of research talent, applied talent, science and technology talent. The innovation is the commonality of all types of talent.

\section{THE INHERENT REGULATION OF IDEOLOGICAL AND POLITICAL EDUCATION IN COLLEGES AND UNIVERSITIES}

Ideological and political education is social practice that the society or social groups exert purposeful, planned and organized influences on their members with certain ideological concepts, political opinions and moral standards. And they would get ideological and moral qualities that meet the needs of the society [3].

The ideological and political education in the special social organization is the ideological and political education in colleges and universities. The colleges and universities should take Marxism-Leninism, Mao Zedong Thought and Xi Jinping's socialism with Chinese characteristics as the guiding ideology for ideological and political education. Colleges and universities should carry out ideological and political education for college students. And then, the college students would have the correct world outlook, outlook on life and values. The correct values are the ideological foundations that lead to the realization of all innovation activities in the legal and moral context. In colleges and universities, the ideological and political education would cultivate college students to form good moral and healthy psychological qualities. And the college students should establish the awareness of serving people, conscientiously obey the law and discipline, work hard and make great efforts to contribute their strength to building an innovative nation.

\section{THE QUALITY CHARACTERISTICS OF INNOVATIVE TALENTS}

First, the innovative talents should have the correct values. Innovative personnel should have the correct world outlook, and the outlook on life and values. If people have positive values, they can have strong sense of responsibility toward the society. And they could closely link their own innovation activities with the development of the country and the progress of the society. Also, the innovation would be the pursuit of human beings. Even if people with distorted values have strong ability to innovate, they may only be the danger to society. Innovative talents must have the correct value orientation and the awareness of serving the society. And then, they can truly become talented people for the wellbeing of the human beings.

Second, the innovative talents should have innovative ideas and innovative spirit. Innovative talents must have innovative ideas and innovative spirit. They are the internal driving force of human innovation activities and the potential driving force for human innovation ability. It advocates innovation and persistently pursues new things. And it is the fundamental guarantee for constant innovation of the entire human society. Innovation awareness is the premise of innovation activities. Without the innovation, innovation activities can't be carried out. The sense of innovation is unique. The primary individual's cognition could meet the needs of the development of the society and people. It would cause the motivation to create something unprecedented. The innovative talents would show their intention, wish and vision in creative activities [4]. With the innovation spirit, the innovative talents should comprehensively use the existing knowledge, information, skills and methods to cultivate the thinking ability of putting forward new methods and new ideas. And then, they would have the will, confidence, courage and wisdom to carry out the creation, reform and innovations. The innovative talents should have strong innovation spirit and innovation idea. Also, they should bravely break the routine in practice. Daring to be the first is the motive of the innovative talents. With the perseverance and courage to overcome various setbacks and blows in innovation activities, they pursue the idea and conviction, which is the feature of the innovative talents different from ordinary people.

Third, the innovative talents would have strong curiosity. The innovation idea and exploration desire lie in the strong desire for knowledge. Strong curiosity is the basic condition of innovation. And it drives people to constantly explore the unknown areas. Einstein once said: "I have no special gift. I have only strong curiosity. And the scientific work that drives $m e$ is an unmanageable desire to understand the mysteries of nature, rather than any other feeling". [5] This sentence shows unique scientific spirit. The curiosity drives Einstein to make repeated research. The famous theory of relativity is shown. 


\section{THE ROLE OF IDEOLOGICAL AND POLITICAL EDUCATION IN COLLEGES AND UNIVERSITIES ON THE INNOVATIVE PERSONNEL TRAINING}

The ideological and political education in colleges and universities would guide the political direction of innovative talents. In the process of cultivating innovative talents, we should always uphold the fundamental task of "setting moral education and cultivating people". The firm and correct political orientation should be on the top of teaching management. Through specific practical activities, we should conduct ideological and political education in an in-depth manner. And we also should promptly promote the latest policies, lines and guidelines to help college students improve their ideological and political awareness. Then, the college students would consciously grow into qualified socialists and reliable successors with Chinese characteristics. They would keep the correct ideal direction of life.

The value orientation of innovative talents is guided by ideological and political education in colleges and universities. Ideological and political education helps college students to establish scientific outlook on the world. It has laid solid foundation for their ideological and political understanding. And it has guided the college students to face the values of life from the perspective of social needs. The college students would properly handle the relationship between individuals and society. They would correctly view social values. By establishing scientific outlook on life, values and world outlook, we could ensure that innovative talents uphold and develop socialism with Chinese characteristics and truly realize their social values under the guidance of the scientific outlooks.

Ideological and political education in colleges and universities would cultivate modern thinking consciousness of innovative talents. The modern sense of thinking is an important mental condition for promoting the process of modernization and the progress of spiritual civilization. Therefore, innovative talents must have the modern ideology to adapt to the social development. At present, according to the social development, we should develop the ideological and political education in colleges and universities. It should constantly update, supplement and perfect the contents. With various advanced education methods and carriers, the ideological and political education in colleges and universities digs the educational resources in depth and fosters the college students to have new idea of demonstrating the national spirit. With the most advanced thinking, it should improve the modern quality of innovative talents. Then, they can contribute to the construction of innovative nation.

\section{THE EFFECTIVENESS OF IDEOLOGICAL AND POLITICAL EDUCATION IN COLLEGES AND UNIVERSITIES BASED ON CULTIVATION OF INNOVATIVE TALENTS}

It should give full play to the humanitarianism of ideological and political theory. "Lotus must have the root." The main way of ideological and political work in colleges and universities is classroom teaching. In the new era, general secretary $\mathrm{Xi}$ Jinping put forward that to make the best use of the main channel of classroom teaching is a new demand for ideological and political work in colleges and universities in the new situation. It is necessary to accurately grasp the scientific connotation of the main channel from the combination of history and reality. Therefore, to make the theoretical class of ideological and political education truly becomes one of the important carriers of non-intelligence education in the cultivation of innovative talents. It is necessary to strengthen classroom teaching. It is the core of the main channel. Also, the teachers should be the key in the main channel of the classroom. The teaching materials are important foundation of the main channel of the classroom. The assessment and evaluation is an important guarantee for the main channel of the classroom. We should adhere to the ideological and political theory in the improvement. We should make the improvement in innovation. Also, we would constantly improve the affinity and pertinence of ideological and political education to meet the growth and development needs of innovative talents.

The colleges and universities should innovate the method and content of ideological and political education. It has many innovative methods of ideological and political education. It could change cramming education into exploratory learning. It could change the teaching to the discussion, etc. The colleges and universities should focus on cultivating students' innovation idea, innovative spirit and innovative personality. They should innovate the content and structure of ideological and political education. "The direction affects the road, and the road determines the fate". The content of ideological and political education in colleges and universities in the new era must stand at the height of the development of philosophy and social science centered on the education. It should correctly guide the undergraduates to understand the world and the general trend of China's development, the comparison of Chinese characteristics and international features, the responsibility of the times and historical mission, lofty aspirations and down-to-earth teaching contents. It should improve the ideological and political quality of creative talents. And the college students should deeply be rooted themselves in the fertile land through the development of individuals in opening up a new world.

It should create cultural environment. And it would be conducive to the growth of innovative talents. Colleges and universities are the carriers of excellent cultural inheritance and the ideological and cultural innovation. As cultural practitioners, leaders and bearers, colleges and universities should always regard culture as an essential part of ideological and political education and an important foundation for cultivating innovative talents. "To cultivate the people with the culture" is an age proposition. Also, it is an important content for the implementation of the strategic task of colleges and universities in strengthening and improving ideological and political education. At present, we should look at the long-term mechanism of constructing the ideological and political education in colleges and universities and fostering creative talents in the larger context and history of the new era with socialism. Taking the spiritual culture as the essence, it should integrate the 
mainstream values and enrich the culture and education, strengthen the school spirit, study style, teaching style and class construction. The colleges and universities should make full use of new media platform. The culture and education would have multiplier effect.

\section{CONCLUSION}

To sum up, in the current era of economic and intellectual integration, the key to realize the innovative development in the country is the cultivation of innovative talents. As the main base for national talent cultivation, colleges and universities must shoulder the responsibility and obligation of cultivating innovative talents for the country. In the new period, the ideological and political education plays an increasingly prominent role in the process of cultivating innovative talents. It requires that colleges and universities should further strengthen ideological and political education according to the actual development. The college students would become innovative talents. It is the fundamental guarantee for building the socialist cause.

\section{REFERENCES}

[1] National medium and long-term education reform and development plan $\quad$ (2010-2020) [EB/OL].
. http://www.moe.gov.cn/publicfiles/business/htmlfiles/moe/s4693/201 008/xxgk_93785.html,2010-07-29

[2] Fu Jinjun, Zhao Zudi. Study on the construction of educational environment of innovative personnel training [M]. Beijing: Science Press, 2011: 8.

[3] Chen Wanbo, Zhang Yaocan. Principles of ideological and political education [M]. Beijing: Higher Education Press, 2007.4-4.

[4] http://baike.baidu.com/link?url=g-mj X2y6U0RHqs Igx2m FBIId Via0BP9to Sjr7dt Sicot D1pd_B_mh Oc KRzaxz Jsi

[5] Yuan Weixin. Alternative thinking on the training of innovative talent: Einstein's enlightenment to us [J]. Tianjin Education, 2006 (7): 7. 